\title{
Effects of Sel-Plex on rumen fermentation and purine derivatives of urine in Simmental steers
}

\author{
Q. Liu ${ }^{1,3}$, C. Wang ${ }^{1}$, Y.X. Huang ${ }^{1}$, C.H. Miao' ${ }^{2}$ and D.H. Gao ${ }^{2}$ \\ ${ }^{1}$ College of Animal Sciences and Veterinary Medicine, Shanxi Agricultural University \\ Taigu, 030801 Shanxi, P.R. China \\ ${ }^{2}$ Beijing Alltech Biological Products Co., Ltd. \\ 101407 Beijing, P.R. China
}

\begin{abstract}
This study aimed to evaluate the effects of Sel-Plex on rumen fermentation and microbial protein synthesis in the rumen of steers. Eight ruminally cannulated Simmental steers were used in a replicated $4 \times 4$ Latin square experiment. Treatments were: control (without Sel-Plex), Selow, Se-medium and Se-high with 7.5, 15 and $22.5 \mathrm{mg}$ Sel-Plex per steer per day, respectively. Ruminal $\mathrm{pH}$, total VFA, acetate and butyrate concentration were not affected by the treatment. The ratio of acetate to propionate was linearly reduced with increasing Sel-Plex dose, due to increased propionate production. Ruminal microbial protein synthesis was linearly and quadratically increased with increasing Sel-Plex dose. The results indicate that Sel-Plex potentially improves rumen fermentation. The optimum dose was $15 \mathrm{mg} / \mathrm{d}$ under the present experimental conditions.
\end{abstract}

KEY WORDS: organic selenium, rumen , microbial protein synthesis, beef cattle

\section{INTRODUCTION}

Schwarz and Foltz (1957) proved that selenium is an ingredient of Factor 3 which can prevent liver necrosis in mice. Subsequently, the effects of selenium on animals were extensively studied by nutritionists, showing that it is an essential element. It is a component of GSH-px, a free-radical scavenger that protects the cell membrane from oxidative damage. Most studies have investigated the effect of inorganic selenium on rumen fermentation and production performance (Gunter et al., 2003; Hemingway, 2003); few have addressed the effect of organic selenium on rumen fermentation and digestion. Therefore, the aim of this work

\footnotetext{
${ }^{3}$ Corresponding author: e-mail: liuqiangabc@163.com
} 
was to study the effects of Sel-Plex on ruminal $\mathrm{pH}$ and fermentation as well as on ruminal microbial protein synthesis in beef cattle.

\section{MATERIAL AND METHODS}

\section{Animals and expeirmental design}

Eight ruminally cannulated Chinese Simmental steers at an average age of 2.5 years and $430 \pm 20 \mathrm{~kg}$ body weight, were assigned to a replicated $4 \times 4$ Latin square. Treatments were: control (without Sel-Plex), Se-low, Se-medium and Se-high with 7.5, 15 and $22.5 \mathrm{mg}$ Sel-Plex per steer per day, respectively. Sel-Plex (Se, $1 \mathrm{~g} / \mathrm{kg}$ ) was supplied by Alltech, Inc. Steers were housed in individual pens $(3 \times 3 \mathrm{~m})$ and fed twice daily at 07.00 and $19.00 \mathrm{~h}$. Diets consisted of $60 \%$ maize straw and $40 \%$ concentrate (Table 1). Feed intake was determined before the experiment and in the experimental period was restricted to a maximum of $90 \%$ of ad libitum intake. Experimental periods were 21 days with $11 \mathrm{~d}$ of adaptation and $10 \mathrm{~d}$ of sampling.

Table 1. Ingredient and chemical composition of diet, $\mathrm{g} / \mathrm{kg}$ dry matter

\begin{tabular}{lrlr}
\hline Ingredients & \multicolumn{2}{c}{ Chemicalcomposition } \\
\hline Maize straw & 600 & $\mathrm{NE}_{\mathrm{mf}}{ }^{2}, \mathrm{MJ} / \mathrm{kgDM}$ & 63.0 \\
Maize grain, ground & 208 & $\mathrm{Crudeprotein}$ & 101.1 \\
Wheat bran & 40 & $\mathrm{NDF}$ & 565.1 \\
Soyabean meal & 66 & $\mathrm{ADF}$ & 355.9 \\
Cottonseed cake & 48 & $\mathrm{Ca}$ & 15.6 \\
Rapeseed meal & 20 & $\mathrm{P}$ & 8.2 \\
Calcium carbonate & 5 & & \\
Salt & 4 & & \\
Dicalcium phosphate & 3.5 & & \\
Mineral and vitamin mix $^{1}$ & 5.5 & & \\
\hline
\end{tabular}

${ }^{1}$ contained, ppm: Co 42, Cu 3500, Fe 20,000, Mn 12,000, Zn 12,000, I 1200, Se 600, IU/g: vit. A 3000 , vit. D 500, vit. E 15

${ }^{2} \mathrm{NE}_{\mathrm{mf}}$ was estimated using the Chinese Beef Nutrition Requirement (Feng, 2000)

\section{Sample collections and determination}

Rumen fluid was collected at 0,3,6, and $9 \mathrm{~h}$ after the $7 \mathrm{a} . \mathrm{m}$. feeding during $\mathrm{d} 19$ and 20 of the experimental period. $\mathrm{pH}$ was immediately measured potentiometrically. VFA were separated and quantified by gas chromatography (GC102AF, Shanghai Specialties Ltd., China) using a 2-m ( $\varphi$ 4-mm) fused PEG2000, Chromsob W AW DMCS column (Goetsch and Galyean, 1983). Ammonia was determined using the method described by Yang (1996). Ruminal degradation kinetics of the maize straw 
(DM and NDF) were measured using the nylon bag technique on $\mathrm{d} 12$ to 14 of the experimental period (Ørskov and McDonald, 1970; McDonald, 1981). NDF were determined using the methods described by Van Soest et al. (1991), DM according to AOAC (1984). Urine was collected and recorded from d 11 to 21 of the experiment and the $\mathrm{pH}$ brought to below 3 by adding $10 \% \mathrm{H}_{2} \mathrm{SO}_{4}$. At the end of the collection, 20 $\mathrm{ml}$ of urine samples were diluted to $100 \mathrm{ml}$ with distilled water and then divided into 2 subsamples. Allantoin and uric acid in urine were determined using a UV-2100 spectrophotometer and IEEA procedures (1997). Ruminal microbial N synthesis was calculated according to Chen and Gomes (1992).

\section{Statistical analysis}

The data were analysed using the mixed model procedure (Proc Mixed; SAS, 1996) to account for the effects of square, period within square, animal within square and treatment. Linear and quadratic orthogonal contrasts were tested using the CONTRAST statement of SAS.

\section{RESULTS}

Ruminal $\mathrm{pH}$ and total VFA concentrations did not differ between the control and Sel-Plex treatments and did not increase with increasing Sel-Plex supplementation (Table 2). On the other hand, propionate (as \% of total VFA) increased linearly. Consequently, the ratio of acetate to propionate was reduced linearly $(\mathrm{P}<0.01)$. The ammonia $\mathrm{N}$ content was reduced either linearly or quadratically $(\mathrm{P}<0.01)$ with increasing Sel-Plex supplementation.

Table 2. Effects of Sel-Plex supplementation on ruminal $\mathrm{pH}$ and fermentation

\begin{tabular}{|c|c|c|c|c|c|c|c|}
\hline \multirow{2}{*}{ Item } & \multicolumn{4}{|c|}{ Treatments } & \multirow{2}{*}{$\mathrm{SE}$} & \multicolumn{2}{|c|}{ Contrast, $\mathrm{P}<$} \\
\hline & control & Se-low & Se-med & Se-high & & linear & quadratic \\
\hline$\overline{\mathrm{pH}}$ & 6.72 & 6.66 & 6.59 & 6.60 & 0.03 & ns & ns \\
\hline Total VFA, mM & 70.43 & 74.37 & 75.12 & 73.98 & 0.97 & ns & ns \\
\hline $\begin{array}{c}\mathrm{Mol} / 100 \mathrm{~mol} \\
\text { acetate, } \mathrm{A}\end{array}$ & 69.76 & 68.07 & 67.29 & 67.55 & 0.76 & ns & ns \\
\hline propionate, $\mathrm{P}$ & $22.82^{\mathrm{b}}$ & $24.49^{\mathrm{a}}$ & $25.07^{\mathrm{a}}$ & $24.76^{\mathrm{a}}$ & 0.33 & 0.01 & ns \\
\hline butyrate & 7.43 & 7.45 & 7.63 & 7.69 & 0.12 & ns & ns \\
\hline$A: P$ & $3.05^{\mathrm{a}}$ & $2.78^{\mathrm{b}}$ & $2.68^{\mathrm{b}}$ & $2.73^{\mathrm{b}}$ & 0.11 & 0.01 & ns \\
\hline Ammonia $\mathrm{N}, \mathrm{mg} / 100 \mathrm{ml}$ & $9.68^{\mathrm{a}}$ & $8.43^{\mathrm{b}}$ & $8.11^{\mathrm{c}}$ & $8.57^{\mathrm{b}}$ & 0.17 & 0.01 & 0.01 \\
\hline
\end{tabular}

${ }_{\mathrm{a}, \mathrm{b}, \mathrm{c}}$ means in the same row with a different superscript are significantly different at $\mathrm{P}<0.05$

Ruminal soluble, potential degradable fractions and ED of DM were linearly increased, but the degradation rate decreased linearly with increasing Se 
supplementation (Table 3). A quadratic response of ruminal digestion kinetics to the dose of Se supplementation was also detected. However, only a linear response of the soluble fraction, and quadratic response of ED to the dose of $\mathrm{Se}$ supplementation were detected in the maize straw NDF digestion kinetics.

Table 3. In situ ruminal digestion kinetics and effective degradability (ED) of maize straw

\begin{tabular}{|c|c|c|c|c|c|c|c|}
\hline \multirow{2}{*}{ Item } & \multicolumn{4}{|c|}{ Treatments } & \multirow{2}{*}{ SE } & \multicolumn{2}{|c|}{ Contrast, $\mathrm{P}<$} \\
\hline & control & Se-low & Se-med & Se-high & & linear & quadratic \\
\hline \multicolumn{8}{|l|}{$\overline{\mathrm{DM}}$} \\
\hline $\mathrm{a}$ & $0.116^{\mathrm{c}}$ & $0.200^{\mathrm{b}}$ & $0.280^{\mathrm{a}}$ & $0.126^{\mathrm{c}}$ & 0.015 & 0.01 & 0.01 \\
\hline $\mathrm{b}$ & $0.691^{\mathrm{b}}$ & $0.712^{\mathrm{b}}$ & $0.719^{b}$ & $0.871^{\mathrm{a}}$ & 0.021 & 0.01 & 0.05 \\
\hline $\mathrm{c}$ & $0.018^{\mathrm{a}}$ & $0.013^{b}$ & $0.009^{\mathrm{b}}$ & $0.008^{b}$ & 0.001 & 0.01 & 0.05 \\
\hline ED & $0.403^{\mathrm{c}}$ & $0.450^{\mathrm{ab}}$ & $0.464^{\mathrm{a}}$ & $0.438^{\mathrm{b}}$ & 0.006 & 0.01 & 0.01 \\
\hline \multicolumn{8}{|l|}{$\mathrm{NDF}$} \\
\hline $\mathrm{a}$ & 0.031 & 0.036 & 0.061 & 0.059 & 0.006 & 0.04 & ns \\
\hline $\mathrm{b}$ & 0.894 & 0.874 & 0.861 & 0.933 & 0.025 & $\mathrm{~ns}$ & ns \\
\hline $\mathrm{c}$ & 0.011 & 0.011 & 0.011 & 0.007 & 0.003 & ns & ns \\
\hline ED & $0.293^{\mathrm{c}}$ & $0.330^{\mathrm{b}}$ & $0.380^{\mathrm{a}}$ & $0.329^{b}$ & 0.009 & 0.01 & 0.01 \\
\hline
\end{tabular}

a,b, c means in the same row with a different superscript are significantly different at $\mathrm{P}<0.05$

Daily urinary excretion of uric acid was not affected by the treatment, but urinary excretion of allantoin as well as total PD was quadratically affected $(\mathrm{P}<0.01)$ by Se supplementation (Table 4). Consequently, the estimated intestinal flow of microbial $\mathrm{N}(\mathrm{g} / \mathrm{d})$ was quadratically increased $(\mathrm{P}<0.01)$ with increasing Se supplementation.

Table 4. Effects of Sel-Plex on purine derivatives excreted in urine

\begin{tabular}{lcccccccc}
\hline & \multicolumn{4}{c}{ Treatments } & & \multicolumn{2}{c}{ Contrast, $\mathrm{P}<$} \\
\cline { 2 - 4 } Item & control & Se-low & Se-med & Se-high & SE & & linear & $\begin{array}{c}\text { quadra- } \\
\text { tic }\end{array}$ \\
\hline Allantoin, mmol/day & $83.30^{\mathrm{d}}$ & $157.07^{\mathrm{b}}$ & $173.76^{\mathrm{a}}$ & $139.86^{\mathrm{c}}$ & 2.40 & 0.01 & 0.01 \\
Uric acid, mmol/day & 7.45 & 8.31 & 8.84 & 8.56 & 0.37 & $\mathrm{~ns}$ & $\mathrm{~ns}$ \\
Total PD, mmol/day & $90.75^{\mathrm{d}}$ & $165.38^{\mathrm{b}}$ & $182.60^{\mathrm{a}}$ & $148.42^{\mathrm{c}}$ & 3.41 & 0.01 & 0.01 \\
Absorption, mmol/day & $48.73^{\mathrm{d}}$ & $123.36^{\mathrm{b}}$ & $140.58^{\mathrm{a}}$ & $106.40^{\mathrm{c}}$ & 2.63 & 0.01 & 0.01 \\
Microbial N, g/day & $47.07^{\mathrm{d}}$ & $110.90^{\mathrm{b}}$ & $125.64^{\mathrm{a}}$ & $96.40^{\mathrm{c}}$ & 2.25 & 0.01 & 0.01 \\
\hline
\end{tabular}

$\mathrm{a}, \mathrm{b}, \mathrm{c}, \mathrm{d}$ means in the same row with a different superscript are significantly different at $\mathrm{P}<0.05$

\section{DISCUSSION}

Supplementation of the steer diet with Sel-Plex altered the rumen fermentation pattern from acetate to propionate as shown by an apparent reduction in the ratio 
of acetate to propionate with increasing Se doses. Ruminal $\mathrm{pH}$ (range from 6.60 to 6.72) in the present study was in the optimum range for cellulolytic bacteria activity (Russell and Wilson, 1996). Rumen VFA concentration reflects the equilibrium between absorption and production of VFA rather than a direct relation with rumen digestion. In in vitro experiments, acetate and butyrate concentrations decreased significantly by supplementation with $0.2 \mathrm{mg} \mathrm{Se}\left(\mathrm{Na}_{2} \mathrm{SeO}_{3}\right)$ per $\mathrm{kg} \mathrm{DM}$, propionate increased significantly, the ratio of acetate and propionate decreased significantly, total VFA showed no significant difference (Wang and Dong, 1996; Lu et al., 1999). Total VFA, acetate and propionate and the ratio of acetate and propionate decreased slightly and the digestibility of NDF was not significantly affected by supplementation with $0.2 \mathrm{mg} \mathrm{Se}\left(\mathrm{Na}_{2} \mathrm{SeO}_{3}\right.$ and $\left.\mathrm{Na}_{2} \mathrm{SeO}_{4}\right)$ per $\mathrm{kg} \mathrm{DM}$ in sheep (Serra et al., 1994). Proteolytic activity of bacteria increased due to Sel-Plex supplemention at $15 \mathrm{mg}$ per day, and consequently NDF degradability of maize straw, CP degradability of soyabean meal and propionate increased.

It is possible that reduction of ammonia $\mathrm{N}$ concentration was due to increased consumption of ammonia $\mathrm{N}$ by enhanced growth of ruminal microbial populations, especially the fibre-degrading populations, with Se supplementation or increased ammonia absorption from the rumen. Cellulolytic bacteria derive their $\mathrm{N}$ exclusively from ammonia (Russell et al., 1992). Ab sorbed purines are almost completely converted into uric acid during passage across the intestinal mucosa before reaching the liver. Uric acid can then be converted into allantoin. Allantoin and uric acid are referred to as 'purine derivatives' (PD) (Chen et al., 1996). Allantoin, total PD and increased intestinal flow of microbial $\mathrm{N}$ indicated that Sel-Plex promoted the utilization of ruminal ammonia $\mathrm{N}$ by rumen bacteria, and microbial protein synthesis.

\section{CONCLUSIONS}

Supplemntation of Sel-Plex in the diet of steers altered the rumen fermentation pattern to more propionate production and microbial production in the rumen. The optimum dose of Sel-Plex in the present experimental conditions was $15 \mathrm{mg} / \mathrm{d}$.

\section{REFERENCES}

AOAC, 1984. Association of Official Analytical Chemists, Official Methods of Analysis. 14 $4^{\text {th }}$ Edition. Washington, DC

Chen X.B., Gomes M.J., 1992. Estimation of microbial protein supply to sheep and cattle based on urinary excretion of purine derivatives - An overview of the technical details. Int. Feed Res. Unit, Occasional Publication. Rowett Research Institute, Bucksburn, Aberdeen (UK)

Chen X.B., Matuszewski W., Kowalczyk J., 1996. Determination of allantoin in biological cosmetic and pharmaceutical samples. J. AOAC Int. 79, 628-635 
Feng Y.L., 2000. Beef Cattle Nutrient Requirements and Feeding Standard (in Chinese). China Agriculture University Press, Beijing, pp. 19-26

Feng Y.L., 2004. Ruminant Animal Nutrition (in Chinese). China Science Press, Beijing, pp. 575576

Goetsch A.L., Galyean M.L., 1983. Influence of feeding frequency and passage of fluid and particulate markers in steers fed a concentrate diet. Can. J. Anim. Sci. 63, 727-730

Gunter S.A., Beck P.A., Phillips J.M., 2003. Effects of supplementary selenium source on the performance and blood measurements in beef cows and their calves. J. Anim. Sci. 81, 856-864

Hemingway R.G., 2003. The influences of dietary intakes and supplementation with selenium and vitamin $\mathrm{E}$ on reproduction diseases and reproductive efficiency in cattle and sheep. Vet. Res. Commun. 27, 159-174

IAEA, 1997. Estimation of rumen microbial protein production from purine derivatives in urine. International Atomic Energy Agency. A laboratory manual for the FAO/IAEA Co-ordinated Research Programme on Development, Standardization and Validation of Nuclear Based Technologies for Measuring Microbial Protein Supply in Ruminant Livestock for Improving Productivity. IAEA-TECDOC-945. Vienna, pp. 31-36

Lu Y.H., Wang Y.S., Dong X.X., 1996. Effects of selenium supplementation in diet on the ruminal digestion and metabolism of goats. Acta Agr. Univ. Henanensis 30, 33-36

Lu Y.H., Wang Y.Y., Nie F.R., Li H.P., Dong X.X., 1999. Study on effect of selenium on in vitro rumen digestion and metabolism of goat. Acta Agr. Univ. Henanensis 33, 311-314

McDonald I., 1981. A revised model for the estimation of protein degradability in the rumen. J. Agr. Sci. 96, 251-252

Ørskov E.R., McDonald I., 1970. The estimation of protein degradability in the rumen from incubation measurements weighted according to rate of passage. J. Anim. Sci. 92, 499-503

Russell J.B., O’Connor J.D., Fox D.G., Van Soest P.J., Sniffen C.J., 1992. A net carbohydrate and protein system for evaluating cattle diets. I. Ruminal fermentation. J. Anim. Sci. 70, 3551-3561

Russell J.B., Wilson D.B., 1996. Why are ruminal cellulolytic bacteria unable to digest cellulose at low pH? J. Dairy Sci. 79, 1503-1509

SAS, 1996. Statistics, Version 7 Edition. SAS Institute Inc. Cary, NC

Schwarz K., Foltz K.M., 1957. Selenium as an integral part of Factor 3 against dietary necrotic liver degeneration. J. Amer. Chem. Sci. 79, 3292-3293

Serra A.B., Nakamura K., Matsui T., Harumoto T., Fujihara R., 1994. Inorganic selenium for sheep. Its influence on rumen bacterial yield, volatile fatty acid production and total tract digestion of timothy hay. Asian-Austr. J. Anim. Sci. 7, 91-96

Van Soest P.J., Robertson J.B., Lewis B.A., 1991. Methods for dietary fiber, neutral detergent fiber and non-starch polysaccharides in relation to animal nutrition. J. Dairy Sci. 74, 3583-3597

Yang S., 1996. Feed Analysis and Quality Determination (in Chinese). Beijing Agriculture University Press, Beijing, pp. 171-172 